\title{
ObYeKTIVITAS TeleVisi DALAM PILKAdA DKI JAKARTA 2017
}

\author{
${ }^{1}$ Indrabayu Muhammad, ${ }^{2}$ Suhendra Atmaja, ${ }^{3}$ Endang Setiyowati
}

\author{
Mahasiswa STIKOM InterStudi 2017 \\ email: indrabayum@gmail.com,dosenngehit99@gmail.com,setiowati@gmail.com
}

\begin{abstract}
Abstrak. Konglomerasi media memang sangat berpengaruh pada isi konten televisi, khususnya pemberitaan. Media massa khususnya televisi memrosesnya dengan melakukan berbagai macam pembingkaian berita. Pembingkaian terkait dengan bagaimana suatu media mengkonstruksi peristiwa menjadi sebuah realitas berita. Pemahaman individu dan ideologi organisasi adalah faktor utama terjadinya sebuah framing. Tujuan penelitian ini untuk menggambarkan dan menganalisis dua talkshow berita besar di Indonesia dalam membingkai suatu kasus. Paradigma dalam penelitian ini adalah konstruksionis yang bersifat kualitatif deskriptif. Teori yang digunakan ialah Konstruksi Sosial Peter L. Berger \& Thomas Luckmann serta teori Hierarchy of Influences dari Pamela J. Shoemaker dan Stephen D Reese (1966) dan teori Semiotika Roland Barthes. Peneliti menggunakan model analisis framing Pan dan Kosicki dengan kerangka konsep obyektivitas. Metodologi yang digunakan dalam penelitian ini adalah Deskriptif Kualitatif dengan analisis data Analisis Framing. Hasil dari penelitian ini adalah talkshow "Mata Najwa" cenderung melakukan framing lebih tegas ke salah satu calon gubernur sehingga terkesan tidak obyektif. Sama halnya dengan "Rosi" yang cenderung lebih dekat dan akrab pada salah satu pasangan kandidat sehingga terkesan tidak obyektif. Kesimpulan dari penelitian ini adalah, masih kurangnya unsur obyektivitas dalam pertelevisian Indonesia, khususnya dalam program informasi, yang seharusnya mengusung unsur obyektivitas dalam menyajikan informasi.
\end{abstract}

Kata kunci : Pemberitaan, Konstruksi realitas sosial, Pembingkaian.

\section{Pendahuluan}

Terkait dengan Obyektivitas suatu media, sudut pandang yang diambil televisi dalam menyajikan berita bukan hanya sekedar untuk menjadi pembeda dengan televisi lain, tetapi bisa saja ini menjadi salah satu strategi dalam mengkonstruksi fakta. Berita dalam pandangan konstruksi sosial bukan merupakan peristiwa atau fakta dalam arti yang real, dalam hal ini realitas bukan bulat-bulat menjadi berita. Dalam proses internalisasi, wartawan menyertakan dirinya untuk memaknai realitas, dengan kata lain, realitas yang ada di media tidak sepenuhnya obyektif.. Konsepsi tentang fakta diekspresikan untuk melihat realitas. Hasilnya adalah sebuah berita yang merupakan produk dari proses interaksi dan dialektika tersebut. (Eriyanto, 2002)

Fenomena konglomerasi media memang sangat berpengaruh terhadap isi konten dan obyektivitas media. Hal ini bisa jelas terlihat dari cara media membingkai suatu peristiwa melalui programnya. Dalam konteks teori hegemoni yang dikemukakan oleh Antonio Gramsci, konglomerat media menghegemoni, menguasai, dan mendominasi media untuk kepentingan diri mereka. (Ks, 2009).

Berdasarkan konsep obyektivitas yang dikemukakan oleh Westertahl (McQuail, 2010) yang menjelaskan 
bahwa obyekivitas terdiri dari keberimbangan dan faktualitas, maka perlakuan terhadap kedua narasumber pada program "Mata Najwa" dan "Rosi" harus berimbang. Termasuk dari sisi keseimbangan materi pertanyaan untuk kedua calon, angle kamera, serta sikap moderator terhadap narasumber harus obyektif dan berimbang, karena semua itu dapat memberikan penekanan dan makna-makna tertentu yang dapat menggiring opini.

Dalam teori Konstruksi Sosial atas Realitas, Peter L. Berger dan Thomas Luckmann mengatakan bahwa kenyataan sosial diciptakan oleh manusia secara subyektif melalui proses eksternalisasi. Sebagaimana kenyataan obyektif yang yang mempengaruhi manusia melalui internalisasi. Berger memandang masyarakat sebagai produk manusia dan manusia adalah produk masyarakat, dengan kata lain, ada hubungan timbal balik antara manusia dan institusi masyarakat yang saling mempengaruhi satu sama lain dalam menciptakan kenyataan sosial. Sama halnya seperti media, media dipandang bukan sebagai saluran yang bebas dan netral, melainkan sebagai subyek yang mengkonstruksi realitas, dimana para pekerja yang terlibat dalam memproduksi pesan juga mengikutsertakan pandangan, bias, dan keberpihakannya, karena itu, sangat mungkin terjadi suatu peristiwa yang sama dikonstruksi secara berbeda. (Luckmann, 1962)

Pada pilkada DKI Jakarta 2017, terdapat banyak kontroversi mulai dari unjuk rasa berjilid hingga isu SARA dan tensi politik yang tinggi. Saling lempar dan adu argumen seputar pilkada menjadi santapan yang rutin disuguhkan oleh media kepada masyarakat. Dalam hal ini obyektivitas sebuah berita tidak lagi dihiraukan, demi kepentingan politik segelintir orang. Nuansa kapitalis dan rasa haus kekuasaan menyelimuti isi pemberitaan, hingga melupakan peran utama suatu media, yaitu sebagai sumber informasi yang netral dan pengawas pemerintahan serta menyajikan berita yang proporsional dan komperhensif. (Kovach, 2001)

Seperti pada program Mata Najwa di Metro TV dan Kompas TV. Dalam program ini fenomena pilkada dikemas dalam bentuk talkshow yang bertajuk debat antarkandidat dan dipimpin oleh moderator. Kedua program ini membingkai berita pilkada dengan kemasan yang berbeda tapi "sama". Aroma keberpihakan pada salah satu kandidat dapat tercium dari berbagai sudut, mulai dari angle kamera, Dalam sebuah komposisi gambar, penataan elemen-elemen pada gambar tersebut memiliki tanda-tanda yang menimbulkan makna. Roland Barthes menggunakan istilah "pesan ikonik yang terkodekan", yaitu merupakan konotasi visual yang diturunkan dari penataan elemenelemen visual dalam komposisi gambar. (Sobur, 2016).

Kemudian sikap moderator dan pertanyaan serta pernyataan yang dilontarkan oleh moderator. Seperti yang dikatakan Van Zoest (1991:70), bahwa sebuah teks tak terlepas dari ideologi dan memiliki kemampuan untuk memanipulasi pembaca atau pemirsa ke arah suatu ideologi. (Sobur, 2016).

Berlatarkan pemain politik dan pengusaha besar menjadi salah satu daya tarik bagi peneliti untuk menilik lebih jauh tentang obyektivitas pemberitaan yang dibingkai oleh kedua stasiun televisi ini. Penelitian menggunakan metode analisis framing telah banyak dilakukan, namun menurut peneliti masih terdapat kekurangan seperti kurangnya indikator yang diamati. Untuk itu peneliti berusaha 
melengkapi itu dengan melakukan penelitian ini.

Berdasarkan masalah di atas, maka peneliti merumuskan : Bagaimana obyektivitas media; yakni pada program "Mata Najwa" dan "Rosi" dalam membingkai pemberitaan atas realitas debat PILKADA DKI Jakarta 2017 ?

\section{Kerangka Konsep}

\section{Obyektivitas}

Salah satu ciri utama dari obyektivitas adalah penggunaan posisi yang tidak terikat dan netralitas dari obyek pemberitaan. Kemudian, tidak partisanship: tidak mengambil sisi dalam sebuah perselisihan atau menunjukkan bias. Selanjutnya, obyektivitas membutuhkan akurasi dan kriteria lain mengenai kebenaran-truth seperti relevansi dan kelengkapan. (W, 1993).

\section{Konstruksi Realitas Sosial}

Menurut teori Konstruksi Realitas Sosial, setiap peristiwa merupakan fakta yang benar-benar terjadi, kemudian menjadi realitas sosial yang obyektif. Realitas sosial obyektif ini diterima dan diinterpretasikan sebagai realitas sosial subyektif dalam diri pekerja media dan individu yang menyaksikan peristiwa tersebut. Pekerja media mengkonstruksi atau membangun realitas secara subyektif yang sesuai dengan seleksi dan preferensi individu menjadi realitas obyektif yang ditampilkan melalui media dengan menggunakan simbol-simbol. Tampilan realitas di media inilah yang disebut realitas sosial simbolik dan diterima pemirsa sebagai realitas sosial obyektif karena media dianggap merefleksikan realitas sebagaimana adanya. (Luckmann, 1962).

\section{Berita}

Secara sederhana, berita didefinsikan sebagai laporan tentang peristiwa dan pendapat. Intinya, berita memuat tiga hal: keterangan atau laporan, peristiwa, dan pendapat. Batasan yang sangat sederhana, tapi di dalamnya memuat kesederhanaan pembingkaian fakta untuk menyampaikan pesan secara apa adanya. Selain itu, berita juga merupakan cermin dan refleksi dari kenyataan. Karena itu, berita haruslah sama dan sebangun dengan fakta yang hendak diliput. (Eriyanto, 2002).

\section{Penelitian Terdahulu}

Dalam penelitian ini, referensi penelitian yang peneliti gunakan adalah penelitian dari Rafik Daris Salam, dengan judul "Konstruksi Realitas Berita Tentang Prabowo Dalam Kasus Hak Asasi Manusia (HAM) tahun 1998 di Metro TV". Penelitian tersebut menggunakan teori konstruksi realitas sosial dan analisis skematik, dan menggunakan metode analisis data analisis framing, penelitian ini dilakukan pada tayangan berita, untuk melihat bagaimana pembingkaian yang dilakukan dalam berita televisi. namun kekurangan dalam penelitian ini adalah hanya meninjau dari satu stasiun televisi saja, sehingga tidak ada pembanding yang bisa dijadikan acuan dalam menilik obyektivitas sebuah stasiun televisi atas kasus pemberitaan.

Kemudian peneliti juga menggunakan penelitian dari Rakhmania Nur Inayati, dengan judul "Analisis Framing Pemberitaan Kasus Pelanggaran Kode Etik Oleh Ketua DPR Dalam Program Talkshow "Mata Najwa dan "Indonesia Lawyer Club". Peneliti menggunakan penelitian ini sebagai acuan untuk mengetahui bagaimana cara melihat framing media 
berdasarkan konsep obyektivitas Westertahl, model hirarkis, dan teori konstruksi realitas sosia yang dilakukan dalam tayangan berita berbentuk talkshow. Namun peneliti masih menemukan kekurangan dari penelitian ini, yaitu kurang mendetail dalam menjabarkan dan melihat framing yang dibentuk oleh kedua televisis berita tersebut, sehingga argumen dalam penelitian tersebut kurang kuat. Untuk itu, dengan penelitian ini, peneliti mencoba melengkapi kekurangan dari penelitian-penelitian terdahulu.

\section{Sembilan Elemen Jurnalistik}

Dalam Pemberitaan Pilkada DKI yang dikemas dalam bentuk talkshow yaitu program "Mata Najwa" di Metro TV dan Program "Rosi" di Kompas TV, masing masing moderator yaitu Najwa Shihab dan Rosiana Silalahi memberikan pertanyaan dan pernyataan kepada kedua Kandidat. Dari pertanyaan-pertanyaan tersebut, peneliti melihat adanya ketidakberimbangan dalam memberikan pertanyaan yang disebabkan oleh berbagai faktor yang disinyalir adanya keberpihakan terhadap salah satu kandidat gubernur. Hal ini terlihat dari jumlah pertanyaan yang diajukan serta durasi dan sikap moderator yang lebih tegas terhadap salahsatu kandidat saja. Padahal menurut Sembilan elemen jurnalistik, Jurnalis harus menjadikan beritanya komprehensif dan proporsional, dengan kata lain harus obyektif. (Kovach, 2001)

\section{Komunikasi Massa}

Wright mengatakan bahwa komunikasi massa memiliki karakter khalayak yang relatif besar, heterogen dan anonim, pesan disampaikan secara terbuka, seringkali dapat mencapai khalayak secara serentak, bersifat sekilas, serta komunikator cenderung berada dalam organisasi yang kompleks. Dengan kata lain media massa mampu membolak-balikkan persepsi dan opini dengan mudah. Media massa dapat menjadi senjata yang sangat ampuh untuk pencitraan politik. Tak heran banyak pemain politik yang berbondong-bondong terjun ke industri media. Seperti Metro TV dan Kompas TV yang berlatarkan pemain besar duniapolitik dan juga pemain besar di dunia bisnis. Karena itu tidak menutup kemungkinan bahwa kepentingan pribadi para pemilik turut diikutsertakan dalam isi konten media. (Rakhmat, 1994).

Berdasarkan pendapat kaum neo-Marxis, yaitu para pemikir yang meneruskan gagasan Karl Marx, memandang media komersial sebagai sarana yang penting untuk mempengaruhi cara pandang dan sikap masyarakat, yang pada akhirnya akan memperkuat dominasi para borjuis atas kaum proletar, artinya media tidak lagi dipandang sebagai suatu badan yang independen dan otonom, melainkan sebagai alat ideologis yang dimanfaatkan para pemodal untuk mencapai tujuan politiknya, sehingga isi media diarahkan bukan untuk kepentingan publik, melainkan untuk kepentingan ekonomi politik para penguasa media tersebut. Sama halnya seperti pada fenomena pilkada DKI yang berbalut banyak kepentingan bisnis dan politik para pemilik media. (Armando, 2016).

Pada bahasan penelitian ini, Hierarchy of Influence tercermin pada Najwa Shihab; baik secara individu maupun organisasional. Secara individu, Najwa merupakan jurnalis yang memiliki pemikiran tajam dan kritis sehingga mempengaruhi program yang dibawakannya. Sedangkan dari sisi struktur organisasional, Najwa merupakan orang yang cukup berpengaruh di pemberitaan Metro TV. Posisi tersebut menjadi penting dalam 
membentuk bingkai mana yang akan disajikan dalam kemasan program "Mata Najwa". Sementara Rosiana Silalahi, adalah seorang jurnalis senior yang pernah menjadi ketua redaksi di beberapa televisi. Dan secara struktur organisasional, Rosi merupakan ketua redaksi Kompas $T V$. Posisi penting milik Najwa maupun Rosi menunjukkan sebuah tingkatan individual maupun oganisasional yang mempengaruhi rutinitas media. (Reese, 1996).

Dalam penelitian pemberitaan terkait debat Pilkada DKI 2017, mengambil contoh dua televisi berita yang memiliki tendensi 'berat sebelah'. Kedua aspek turunan baik faktualitas dan imparsialitas ini akan melihat bagaimana media menyeleksi dan membangun isu, merumuskan pemikiran dalam pertanyaan, lalu memisahkan fakta dan opini, serta proporsi yang seimbang serta perlakuan yang berimbang pada setiap kandidat. Skema dan penjelasan tersebut kemudian digunakan untuk mempermudah analisa tayangan talkshow "Mata Najwa" dan "Rosi" dibedah dari obyektivitas kedua program. (W, 1993).

\section{Kode Etik Jurnalistik}

Berita disusun berdasarkan atas realitas atau fakta yang disaksikan, didengar, dan dirasakan wartawan atau jurnalis, tanpa mencoba mengembangkan gagasan-gagasan ideologi atau kepentingan lain di balik kalimat, narasi, atau gambar-gambar. Bill Kovach dan Rosentiel mengungkapkan kaidah-kaidah yang juga dipositivistikkan sebagai teknik reportase, penulisan berita, dan kode etik jurnalistik yang berlaku universal sebagai standar teknik reportase, penulisan berita, dan etika jurnalistik yang mesti diemban jurnalis dan media. Berdasarkan pernyataan tersebut peneliti mencoba untuk menilik obyektivitas dalam berita yang dibingkai oleh dua stasiun televisi yaitu, Metro TV dalam program "Mata Najwa", dan Kompas TV dalam program "Rosi". (Tuchman, 1978).

\section{Framing}

Lebih lanjut membahas mengenai framing, dalam teknik produksi siaran televisi terdapat berbagai framing/ pembingkaian obyek yang memiliki makna guna mendukung sebuah konstruksi realitas/ cerita tertentu. Jenis-jenis Framing yang digunakan oleh sutradara pada umumnya terdiri dari beberapa angle. Angle yaitu fokus pada cerita tertentu; sudut pandang dari si penglihat dan menjelaskan suatu peristiwa. Angle dapat menggiring bias tentang siapa yang bercerita atau dapat menjadikan sebuah peristwa menjadi lebih menarik untuk disaksikan. Dalam pembingkaian berita yang dilakukan oleh program "Mata Najwa" maupun "Rosi", sama sama memperlihatkan perubahanperubahan angle kamera, dari gambar tersebut dapat terlihat kemana arah penggiringan opini yang dilakukan oleh kedua program talkshow ini. (Zettl, Television Production Handbook., 2012)

Penyampaian makna pada iklan televisi memiliki kesamaan dengan penyampaian makna dalam program televisi maupun berita. Roland Barthes memperkenalkan suatu model analisa yang pernah digunakan untuk menganalisa iklan Pasta "Panzani" di televisi, berdasarkan pesan yang dikandungnya. Yaitu : a). Pesan linguistik, yaitu semua kata dan kalimat dalam iklan, dalam iklan pasta "Panzani", secara detonatif kata ini menunjukkan nama produk, namun jika digabungkan dengan kata 'L'Italienne, konotasi yang muncul adalah "sesuatu 
yang berjiwa Italia". b). Pesan ikonik yang terkodekan, merupakan konotasi visual yang diturunkan dari penataan elemen - elemen visual dalam iklan. c). Pesan ikonik tak terkodekan. Istilah ini digunakan Barthes untuk menunjuk denotasi "harfiah", pemahaman langsung dari gambar dan pesan dalam iklan, tanpa mempertimbangkan kode sosial yang lebih luas (atau langue). Dalam program "Mata Najwa" maupun "Rosi", pesan linguistiknya adalah setiap kata dan kalimat yang dilontarkan Najwa maupun Rosi dalam bentuk pertanyaan dan pernyataan kepada kedua kandidat calon gubernur dan wakil gubernur, kemudian pesan ikonik yang terkodekan dalam penelitian ini dapat dicerminkan melalui sudut pandang kamera dan komposisi gambar yang dibentuk dalam program "Mata Najwa" maupun "Rosi". Dan pesan ikonik tak terkodekan dalam kedua program ini adalah detonasi "harfiah" atau pemahaman langsung dari apa yang terlihat dan terdengar dalam program "Mata Najwa" maupun "Rosi". (Sobur, 2016).

Adapun kerangka berpikir peneliti dalam penelitian ini adalah sebagai berikut :

\section{Kerangka Berpikir}

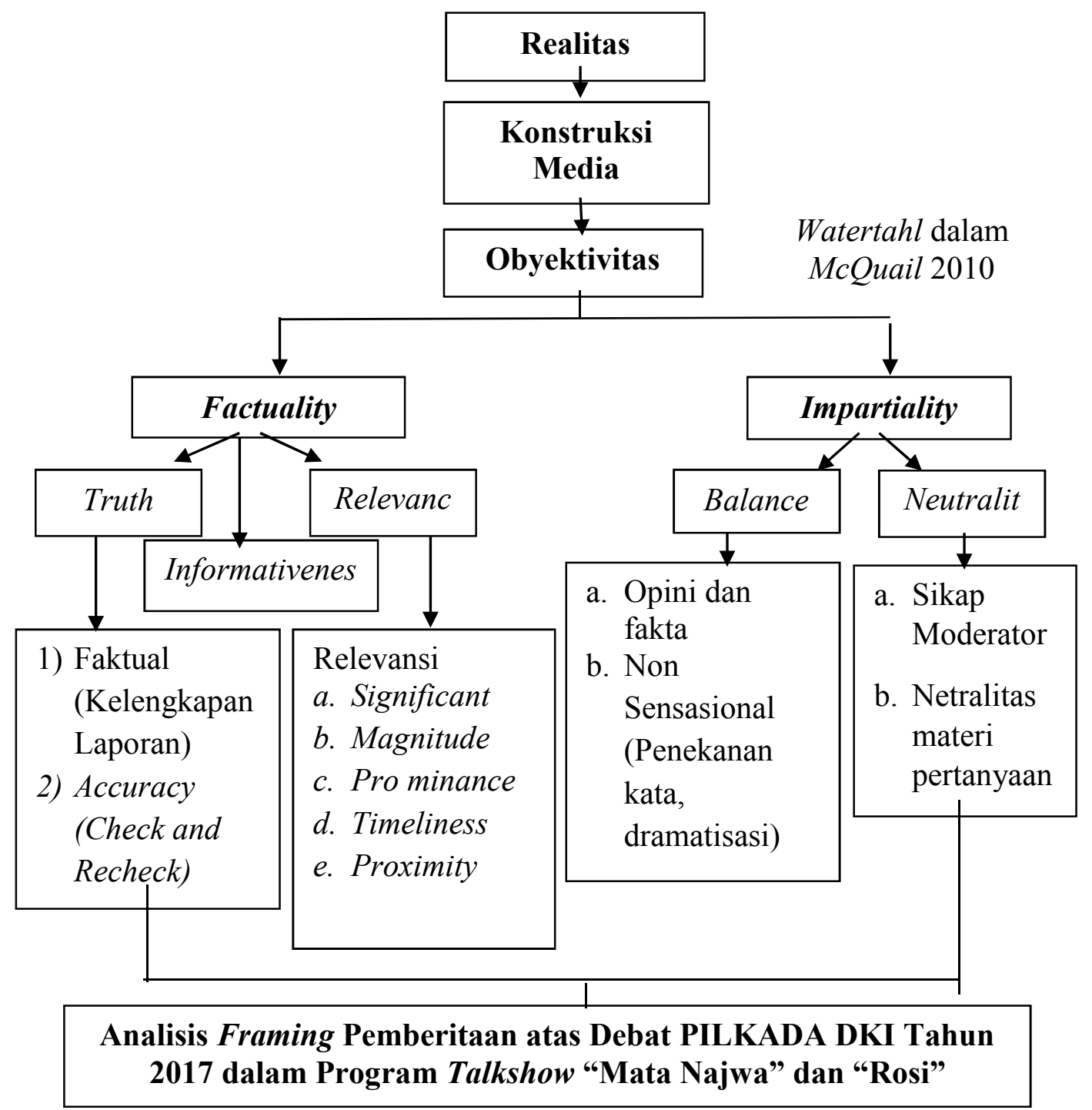




\section{Metodologi Penelitian}

\section{Paradigma Penelitian}

Penelitian ini menggunakan paradigma penelitian konstruksionis. Paradigma konstruksionis memiliki penilaian sendiri tentang bagaimana media, wartawan, dan berita dilihat. Konsep konstruksionis diperkenalkan oleh Peter L. Berger dan Thomas Luckmann. Pandangan Berger bahwa manusia dan masyarakat adalah produk yang dialektis, dinamis, dan plural secara terus-menerus. Menurut Berger, bahwa realitas itu tidak dibentuk secara ilmiah, bukan juga suatu pemberian, melainkan dibentuk dan dikonstruksi. Boleh jadi, pemahaman demikian menyiratkan bahwa realitas berwajah ganda/ plural. Peneliti menggunakan paradigma konstruksionis karena dinilai cocok dengan masalah yang diteliti, yaitu obyektivitas stasiun televisi pada pilkada DKI Jakarta 2017, dalam kasus ini peneliti mencoba melihat bagaimana cara media mengkonstruksi sebuah fakta, karena paradigma konstruksionis juga memandang media bukan sebagai suatu yang netral tetapi sebagai seseuatu yang memproduksi realitas.

\section{Pendekatan Penelitian}

Penelitian ini menganalisa pemberitaan sebuah media (Framing) yang juga termasuk dalam kajian analisis wacana media. Dalam penelitian ini peneliti menjadikan katakata, intonasi, gambar, suara dan sikap sebagai indikator penelitian. (Creswell, 1998; dalam Noor, 2011) menyatakan penelitian kualitatif sebagai suatu gambaran kompleks, meneliti kata-kata, laporan terinci dari pandangan responden, dan melakukan studi pada situasi yang alami. Penelitian kualitatif merupakan riset yang bersifat deskriptif dan cenderung menggunakan analisis dengan pendekatan induktif. Umelihat bagaimana pembingkaian berita yang dilakukan oleh program talkshow "Mata Najwa" dan "Rosi" atas Debat Pilkada DKI Jakarta 2017, maka peneliti menggunakan pendekatan kualitatif. (Moleong, 1993).

Dalam penelitian ini, peneliti berusaha mendeskripsikan suatu gejala atau peristiwa yang aktual, untuk itu peneliti menggunakan metode penelitian kualitatif deskriptif. Karena Pada hakikatnya, penelitian kualitatif deskriptif adalah suatu metode dalam meneliti status kelompok manusia, suatu obyek dengan tujuan membuat deskriptif, gambaran atau lukisan secara sistematis, faktual dan akurat mengenai fakta-fakta atau fenomena yang diselidiki. (Cevilia, 1993).

\section{Metode Penelitian}

Dalam penelitian ini peneliti menggunakan metode analisis framing karena dalam kasus ini peneliti perlu mengamati bagaimana program "Mata Najwa" dan "Rosi" dalam membingkai suatu peristiwa, sehingga dapat terlihat obyektivitas kedua program ini dan kemana penggiringan opini yang dibentuk oleh kedua program ini, berhubung latar belakang kedua program ini adalah stasiun televisi yang dimiliki oleh elit politik dan juga pengusaha besar, sehingga terdapat kecenderungan menyisipkan kepentingan pribadi dalam suatu realitas yang dibentuk oleh media miliknya. Dengan analisis framing peneliti dapat melihat lebih jelas kemana arah pemikiran media dalam membingkai suatu peristiwa, karena dalam hal ini peneliti juga mengambil posisi sebagai penonton yang ikut merasakan pesan yang disampaikan media tersebut.

Analisis Framing, yakni melihat bagaimana media mengkonstruksi realitas, peristiwa yang ada tidak bisa dipahami sebagai sesuatu yang taken for 
granted; tidak berharga atau bernilai. Nilai itulah yang dipahami sebagai realitas yang dikonstruksikan media. Lebih spesifik, bagaimana setiap media membingkai peristiwa dalam konstruksi tertentu. Sehingga yang menjadi perhatian bukan lagi soal media tersebut memberitakan secara positif atau negatif, namun bagaimana bingkai yang dikembangkan oleh media tersebut. (Eriyanto, 2002).

\section{Obyek Penelitian}

Obyek penelitian yang digunakan dalam metode penelitian ini adalah dua program, yaitu "Mata Najwa" di Metro TV serta "Rosi" di Kompas TV. Unit analisis yang digunakan adalah episode khusus debat Pilkada DKI Jakarta 2017 yang diselenggarakan langsung oleh pihak Metro TV dan Kompas TV, dan bukan merupakan acara debat yang diselenggarakan oleh KPU (komisi Pemilihan Umum), serta menghadirkan Basuki Tjahya Purnama dan Anies Rasyid Baswedan secara bersamaan sebagai peserta debat dari program "Mata Najwa" dan "Rosi". Lebih detil, episode "Mata Najwa" yang diteliti adalah "Eksklusif Debat Babak Final Pilkada Jakarta" tanggal 27 Maret 2017. Sedangkan tayangan "Rosi" yang menjadi unit analisis adalah tanggal 15 Desember 2016 dengan judul "Rosi dan Kandidat Pemimpin Jakarta".

\section{Metode Analisis Data}

Metode pengumpulan data primer yang digunakan dalam penelitian ini adalah analisis Framing. Framing atau bingkai yang dipakai baik dalam "Mata Najwa" maupun "Rosi" dianalisa sesuai perangkat Framing sehingga lebih memudahkan peneliti untuk menganalisis dan terlihat perbedaan antara keduanya dalam membingkai realitas atas Debat Pilkada DKI Jakarta 2017.

Pada penelitian ini peneliti menggunakan model Pan dan Kosicki, karena peneliti ingin melihat bagaimana media memproses suatu informasi dan menyeleksi isu serta bagian-bagian dari suatu peristiwa dalam membentuk realitas. Framing dalam konsepsi ini lebih menekankan bagaimana seorang memproses suatu informasi dalam dirinya. Framing dalam konsepsi ini menonjolkan aspek koknitif seseorang. Elemen-elemen yang diseleksi dari suatu isu atau peristiwa tersebut menjadi lebih penting dalam mengetahui pertimbangan dalam membuat keputusan tentang realitas. (Eriyanto, 2002).

Zhongdan Pan dan Gerald M. Kosicki (1992) melalui tulisan mereka "Framing Analysis: An Approach to News Discourse" mengoprasionalisasikan empat dimensi struktural teks berita sebagai perangkat framing: sintaksis, skrip, tematik, dan retoris. Sintaksis, adalah sususan kata atau frase dalam kalimat. Sintaksis menunjuk pada pengertian susunan dan bagian berita headline, lead latar informasi, sumber, penutup- pada satu kesatuan teks berita secara keseluruhan. Unsur sintaksis biasanya memberikan petujuk tentang bagaimana wartawan memaknai peristiwa dan hendak ke mana berita tersebut mau dibawa.

$$
\text { Dalam program "Mata Najwa" }
$$

dan "Rosi", peneliti telah mengkolaborasi antara model framing Pan dan Konsicki dengan konsep obyektivitas Westertahl, sehingga unsur sintaksisnya adalah prangkat framing berupa skema berita, dan unit yang dianalisis adalah unsur imparsial berupa kutipan pertanyaan dari Nitizen, pertanyaan yang diberikan untuk kedua kandidat, aturan main yang diterapkan, dan pernyataan yang dilontarkan oleh 
moderator baik dalam program "Mata Najwa" maupun "Rosi".

Skrip ialah laporan berita yang sering disusun sebagai suatu ceita biasanya menggunakan unsur $5 \mathrm{~W}+1 \mathrm{H}$. Dalam program "Mata Najwa" maupun "Rosi", unsur skrip menggunakan perangkat framing kelengkapan berita, yakni secara imparsial berupa pemilihan narasumber yang diwawancarai dan perilaku penonton yang ada di lokasi dalam program "Mata Najwa maupun "Rosi. Sedangkan tematik, adalah tema yang dihadirkan atua dinyatakan secara tidak lagsung atau kutipan sumber yang dihadirkan dalam rangka mendukung hipotesis. Dalam program "Mata Najwa maupun "Rosi, menggunakan perangkat framing detail, koherensi, bentuk kalimat, dan kata ganti, secara faktual yaitu kalimat-kalimat dalam pertanyaan yang ditujukan pada kedua kandidat, penarikan kesimpulan yang dilakukan moderator terhadap pernyataan dari kedua kandidat dalam program "Mata Najwa" maupun "Rosi". Selanjutnya, retoris merupakan gambaran pilihan gaya yang dipilih oleh wartawan untuk menekankan arti yang ingin ditonjolkan wartawan tersebut. Dalam program "Mata Najwa" maupun "Rosi", menggunakan perangkat framing grafis dan metafora, secara imparsial yaitu, intonasi moderator dalam menyatakan pernyataan atau pertanyaan untuk kedua kandidat, angle kamera, idiom dalam program "Mata Najwa" maupun "Rosi". Kemudian secara faktual yaitu, penekanan kata dan suara-suara yang terdengar saat acara berlangsung baik dalam program "Mata Najwa" maupun "Rosi". Keseluruhan elemen inilah yang dapat menjadi kunci dalam menganalisa Framing pemberitaan pada program "Mata Najwa" dan "Rosi".

\section{Hasil dan Diskusi}

Pembingkaian ini dilakukan pada dua program talkshow di televisi, yaitu "Mata Najwa" di Metro TV dan "Rosi" di Kompas TV. Adapun dalam analisisnya, peneliti menggunakan episode yang spesifik menayangkan debat adu gagasan pada pilkada DKI Jakarta 2017, yakni episode "Mata Najwa" tanggal 27 Maret 2017. Sedangkan episode "Rosi" yang dianalisis adalah tanggal 15 Desember 2016.

Melalui model analisis Pan dan Kosicki yang sudah dikaitkan dengan konsep obyekivitas, penelitian ini berusaha mengkaji bagaimana pembingkaian yang dilakukan kedua media tersebut, apalagi pada pilkada kali ini terdapat salah satu calon yang terlibat beberapa kasus, terutama isu SARA yang menjadi viral serta dibalut dengan tensi politik yang sangat tinggi. Sedangkan pemegang sebagian besar saham Metro $T V$ saat ini adalah salah satu pengusaha properti terbesar di Indonesia, dan pemilik Kompas $T V$ yang merupakan pebisnis besar di bidang media. Kedua talkshow ini sudah memiliki nama dan citra di mata pemirsa televisi. Namun peneliti menilai masih kurang bahkan cenderung tidak obyektif pada pelaksanaannya.

\section{STRUKTUR SINTAKSIS Program "Mata Najwa" :}

Dalam episode "Mata Najwa Eksklusif Babak Final Pilkada Jakarta", tidak ada unsur faktual dalam struktur sintaksisnya, karena tidak ada lead dalam episode ini, dan judul dalam episode ini juga cukup obyektif, yaitu "Mata Najwa Eksklusif Babak Final Pilkada Jakarta", namun dalam episode ini peneliti menilai pembingkaian dari struktur sintaksis pada unsur imparsial. Struktur imparsial pada episode "Mata 
Najwa Eksklusif Babak Final Pilkada Jakarta" ini mengangkat latar informasi tentang debat adu gagasan dan program antara kedua kandidat calon gubernur, yaitu Basuki Tjahya Purnama dan Anies Rasyid Baswedan. Dalam debat ini juga dilampirkan kutipan pernyataan dari kedua kandidat yaitu, pernyataan Anies yang menganggap Basuki telah meniru program-programnya, yaitu program "jaminan hari tua", dan program "wirausaha". Serta pernyataan Basuki yang mengaku tidak mengerti tentang program KJP plus milik Anies dan sedikit menyindir program OKOC milik Anies dengan berkata "Ini bangun siapa bangun duluan, ini OKOC sesungguhnya".

Dalam hal ini Metro $T V$ yang diwakili oleh program "Mata Najwa" lebih dalam menggali informasi mengenai program Anies. Meskipun Najwa tidak mencecar seperti biasanya, namun hal tersebut dapat dilihat dari probing yang lebih banyak diberikan Najwa kepada Anies, yaitu, sebanyak 17 kali dan Basuki hanya 14 kali. Hal ini menunjukkan ketidakpuasan Najwa atas jawaban Anies sehingga lebih dalam menggali informasi terhadap Anies. Kemudian pertanyaanpertanyaan Najwa yang lebih menyinggung Anies, seperti pertanyaan tentang pelajaran kepemimpinan yang diambil dari pak Harto. Bila ditelaah lebih jauh, pak Harto merupakan salah satu pemimpin yang sangat dicintai di negri ini karena ketegasannya dan kemampuannya yang begitu cekatan mengambil keputusan untuk kesejahteraan rakyat. Sedangkan Anies adalah mantan juru bicara Jokowi yang merupakan presiden pilihan partai PDIP pimpinan Megawati yang tidak lain adalah putri dari presiden pertama Indonesia, Soekarno. Seperti yang sama-sama kita ketahui, persepsi tentang Soekarno dan Soeharto adalah dua kubu yang cukup bersebrangan.
Serta posisi Anies yang saat ini diusung oleh partai Gerindra yang dipimpin oleh orang dari era orde baru Soeharto, yaitu Prabowo. Padahal pada Pilpres 2014 lalu Anies sempat memberikan kritik yang tajam pada Prabowo. Peneliti melihat bahwa melalui pertanyaan tersebut, Najwa ingin menggali informasi tentang seberapa dalam pengetahuan Anies tentang kepemimpinan, sekaligus sebagai umpan yang diberikan Najwa untuk menunjukkan ketidakkonsistenan Anies. Kemudian pertanyaan tentang program perumahan untuk rakyat yang mengusung DP nol rupiah, hal ini cukup ramai diperbincangkan di berbagi media karena kemungkinan tidak bisa direalisasikan, mengingat dalam pengajuan kredit, bank harus mendapatkan keuntungan, serta harus mendapat suatu jaminan agar kredit bisa terealisasi. Pertanyaan tersebut juga membuka kesempatan bagi Basuki untuk menyerang Anies dengan wawasan tentang mekanisme keuangan. Lalu pertanyaan tentang Tunjangan Kinerja Daerah, peneliti melihat Najwa lebih dalam menggali informasi tentang hal tersebut dengan agak menekan Anies untuk meminta kepastian apakah akan mempertahankan atau tidak. Dari pertanyaan-pertanyaan tersebut peneliti menganalisa bahwa Najwa sering memberikan umpan berupa pertanyaan untuk Anies, sehingga Basuki punya lebih banyak kesempatan untuk menanggapi program Anies tersebut dan membandingkan dengan program miliknya, serta bisa mengkonfirmasi kekeliruan yang dilontarkan oleh Anies tentang dirinya. Jika dilihat dari porsi yang diberikan Najwa, total durasi Basuki menjawab pertanyaan dan menanggapi adalah 41 menit, sedangkan Anies hanya 38,9 menit. Meskipun hanya sedikit menjawab pertanyaan, justru ini jadi sebuah keuntungan bagi Basuki karena Najwa 
tidak terlalu dalam menggali informasi terhadap Basuki, sehingga Basuki bisa mengkondisikan dirinya semaksimal mungkin dan terlihat lebih unggul. Dengan kesempatan menanggapi yang lebih banyak, yaitu 29 kali, Basuki juga mempunyai amunisi yang lebih banyak untuk melawan argumen Anies, sedangkan Anies hanya 26 kali, sehingga dalam debat ini Basuki menjadi lebih unggul. Dalam program ini juga menampilkan pertanyaan dari nitizen. Dari ribuan pertanyaan yang masuk, pihak "Mata Najwa" memilih 4 pertanyaan yaitu, 2 untuk Basuki dan 2 untuk Anies. Pertanyaan nitizen yang dipilihkan untuk Basuki adalah tentang pengelolaan dan CSR dan kasus reklamasi. Sedangkan untuk Anies adalah tentang isu SARA dan dana kampanye dari Sandi sebesar Rp.62 milyar. Jika dilihat dari nilai kekuatan beritanya, berita tentang kasus kasus SARA merupakan berita yang paling viral dalam PILKADA DKI ini serta Basuki merupakan orang yang paling terlibat dalam kasus SARA tersebut, dan berita tentang dana kampanye 62 milyar rupiah yang disumbangkan Sandi merupakan suatu kesepakatan internal yang terjadi di dalam kubu Anies-Sandi yang berpotensi menyebabkan perpecahan dalam kubu tersebut jika gagal menjadi pemimpin Jakarta. "Mata Najwa" dalam hal ini bukan tanpa alasan memilihkan pertanyaan tentang pemanfaatan isu SARA untuk Anies, dari pertanyaan tersebut terselip pesan tentang "kampanye hitam" yang dilakukan Anies-Sandi, dan "Mata Najwa" berusaha menggali lebih dalam tentang hal itu. Sedangkan pertanyaan tentang kasus dana kampanye 62 milyar rupiah sumbangan Sandi, seakan memutarbalikkan fakta tentang kampanye rakyat yang diusung Anies serta memberikan Basuki kesempatan untuk membandingkan dengan kampanye "uang receh rakyat" yang diusungnya.

Pertanyaan nitizen yang dipilih "Mata Najwa" untuk Basuki adalah tentang kasus pengelolaan dan CSR dan Reklamasi teluk Jakarta. Kasus pengelolan dana CSR merupakan kasus yang sudah lama terjadi sebelum PILKADA berlangsung, dan masih dalam proses penyidikan oleh KPK, dengan kata lain sudah ada proses hukum yang berlangsung dalam kasus ini sehingga Basuki belum tentu bersalah dalam kasus ini. Sama halnya dengan kasus reklamasi teluk Jakarta yang masih dalam proses hukum sehingga mega proyek tersebut belum tentu dinyatakan sebagai suatu kesalahan. Kedua pertanyaan tersebut merupakan kasus yang tidak secara langsung berkaitan dengan PILKADA DKI dan tidak berkaitan dengan Anies. Sedangkan kasus-kasus yang menjadi pertanyaan untuk Anies adalah kasus yang berkaitan dengan Basuki sehingga Basuki punya lebih banyak wawasan tentang kasus tersebut yang dapat dijadikan amunisi untuk melawan argumen Anies.

\section{STUKTUR SKRIP Program "Mata Najwa" :}

Unsur imparsial dari konsep oyektivitas menurut peneliti adalah pemilihan narasumber. Dalam porsi pemilihan narasumber sudah cukup proporsional, yakni Basuki Tjahya Purnama di sebelah kiri Najwa, namun Najwa lebih dalam menggali informasi terhadap Anies yang diposisikan di sebelah kanannya, dengan lebih banyak mengajukan pertanyaan, sehingga membuka kesempatan bagi Basuki untuk menanggapi argumen Anies yang terlihat begitu agresif dalam debat ini.

Tim Mata Najwa juga menempatkan kamera utama sejajar dengan posisi Anies, sehingga angle 
long shot yang diambil dari depan kandidat cenderung menyilang ke arah Basuki dan frame yang dihasilkan pun lebih fokus menanggkap gambar di sekitar posisi Basuki. Berdasarkan penempatan duduk ini, peneliti menganalisa bahwa tim Mata Najwa sudah memiliki arah pemikiran tertentu, menyudutkan suatu pihak yang terbilang berada di ideologi politik yang berbeda dengan Metro TV.

\section{STRUKTUR TEMATIS Program "Mata Najwa" :}

Secara faktual, Saat Anies sedang menjawab pertanyaan tentang KJP plus, Najwa tiba-tiba memotong perkataan Anies dengan kalimat bernada rendah namun terkesan tegas "Baik, waktunya sudah habis mas Anies" , kemudian setelah itu Najwa meminta tanggapan dari Basuki terkait jawaban anis tentang KJP plus tersebut dengan kalimat yang terkesan menyindir Anies "Pak Ahok apakah sudah mengerti sekarang setelah dijelaskan langsung oleh kandidat nomor urut 3 ?". dalam hal ini peneliti menganalisa bahwa melalui isyarat vokal tersebut, Najwa berusaha menunjukkan suatu ekspresi dan maksud tertentu. Hal ini juga selaras dengan apa yang ditekankan Mead tentang pentingnya komunikasi, terutama melalui mekanisme isyarat vokal (bahasa), meskipun teorinya bersifat umum. Namun yang paling potensial menjadi seperangkat simbol pembentuk bahasa adalah isyarat vokal. Dengan demikian, terlihat ada suatu perbedaan dalam perlakuan terhadap kedua kandidat, Najwa seakan lebih tumpul dan lunak ke Basuki, namun tajam dan tegas terhadap Anies.

Penarikan kesimpulan pada episode ini adalah keunggulan Basuki Tjahya Purnama dalam debat ini. Terlihat dari reaksi penonton yang lebih sering bertepuk tangan setelah Basuki menjawab pertanyaan atau menanggapi jawaban Anies. Sedangkan saat Anies menjawab pertanyaan atau menanggapi jawaban Basuki, tepuk tangan penonton lebih sedikit dan lebih sering "menyoraki" Anies. Program "Mata Najwa" menyisipkan pesan kesimpulannya dalam penggalan catatan Najwa yang juga diselingi dengan angle gambar yang mewakili tiap kalimat dalam catatan tersebut. "Mata Najwa" juga sepakat bahwa demokrasi harus ditegakkan dengan tidak melihat perbedaan (dalam konteks ini adalah SARA) dalam menentukan pilihan di kotak suara. "Perdebatan kini menjadi keniscayaan, sebagai satu tahapan dalam pemilihan. Sebuah langkah penting agar demokrasi tak kembali ke masa-masa genting. Karena sudah terlalu lama mufakat jadi kemutlakan saat menjadi beda dianggap kejahatan". Pada saat tulisan kalimat tersebut tampil dilayar, kamera mengambil angle close up ke arah Basuki, sehingga timbul kesan bahwa kalimat tersebut mewakili apa yang terjadi pada Basuki saat ini, hal tersebut juga diperkuat dengan kenyataan bahwa Basuki memang berbeda agama, ras, dan suku, sehingga sangat pas dengan keadaan Basuki. Kemudian kalimat "Dari pada diam-diam saling lempar batu" beriringan dengan angle close up yang di ambil ke arah Anies, kalimat tersebut memberikan kesan bahwa Mata Najwa ingin menjelaskan bahwa Anies memang terlihat tenang dan santun namun diam-diam menyerang. Pernyataan ini juga diperkuat dengan kecurigaan Najwa tentang kampanye hitam yang dilakukan Anies, hal ini terlihat dari pertanyaan Najwa yang menyinggung soal isu SARA untuk Anies. Lalu kalimat "Mendalami masalah rill dengan aksi dipaparkan dengan cara yang rinci” beriringan dengan ekspresi wajah Basuki yang ditampilkan di samping tulisan tersebut, 
hal ini memberikan kesan bahwa katakata tersebut mencerminkan perilaku yang dilakukan Basuki selama debat. Hal ini selaras dengan apa yang dikatakan Van Zoest (1991:70), bahwa sebuah teks tak terlepas dari ideologi dan memiliki kemampuan untuk memanipulasi pembaca atau pemirsa ke arah suatu ideologi.

Secara imparsial, porsi yang diberikan untuk kedua kandidat berbeda tipis. Peneliti mencoba menghitung durasi berbicara yang di berikan pada Basuki dan yang diberikan pada Anies. Waktu dihitung sejak kandidat mulai mengeluarkan suara hingga berhenti berbicara. Waktu yang digunakan Basuki untuk berbicara dalam debat tersebut baik dalam menjawab pertanyaan maupun menanggapi jawaban kandidat lainnya adalah 41 menit. Sedangkan Anies 38,9 menit. Dengan kata lain, Basuki memiliki waktu yang lebih panjang 2 menit 51 detik untuk menyampaikan pendapat dan jawabannya. Dengan selisih waktu selama itu sangatlah bermanfaat untuk menyampaikan pesan di media televisi, mengingat waktu yang dibutuhkan orang untuk memahami pesan di televisi adalah 30 detik.

\section{STRUKTUR RETORIK Program "Mata Najwa" :}

Secara faktual, pada debat tersebut Najwa memanggil Basuki dengan sebutan "Pak Ahok" sedangkan memanggil Anies dengan sebutan "Mas Anies", menurut teori semiotika yang dikembangkan oleh Roland Barthes, panggilan "Pak" memiliki arti secara denotasi yaitu panggilan untuk seorang laki-laki yang berusia paruh baya atau orang tua laki-laki, sedangkan konotasinya adalah panggilan untuk laki-laki dalam konteks formal. Sementara panggilan "Mas" scara detonasi adalah panggilan untuk laki- laki yang lebih tua atau kakak laki-laki dalam bahasa Jawa, sedangkan konotasinya adalah panggilan yang lebih santai atau informal untuk lakilaki yang lebih tua. Sekilas memang terkesan bahwa Najwa lebih dekat dengan Anies karena menmanggil dengan sebutan "mas", namun jika dilihat dari penggalian informasi yang dilakukan Najwa, Anies justru digali lebih dalam dengan diberikan 17 kali probing, sedangkan Basuki hanya 14 kali. Saat debat berlangsung juga terdengar suara tepuk tangan yang meriah saat Basuki selesai menanggapi jawaban Anies perihal DP nol rupiah di program perumahan rakyat, namun setelah itu Anies juga menanggapi kembali tanggapan Basuki tersebut, dan terdengar reaksi penonton yang menyoraki Anies. Hal ini menunjukkan indikasi bahwa sebagian besar penonton di studio lebih bersimpati kepada Basuki, dengan kata lain sebagian besar penonton di studio adalah pendukung Basuki, padahal di awal acara Najwa menyatakan tidak mengundang pendukung dari kedua kandidat. Hal ini menunjukkan ketidakobyektifan program Mata Najwa.

Secara imparsial, ada beberapa angle gambar yang diambil dari belakang Basuki saat Basuki sedang berbicara, sehingga terlihat jelas ekspresi Najwa dan penonton yang begitu memperhatikan tiap kata yang disampaikan Basuki. Dalam hal ini peneliti menganalisa bahwa tim Mata Najwa terkesan ingin menunjukkan kewibawaan serta keunggulan Basuki yang terwujud dari ekspresi Najwa dan penonton yang begitu hikmat menyimak apa yang disampaikan Basuki. Kemudian saat Anies sedang berbicara, tiba-tiba kamera mengalihkan fokusnya menangkap ekspresi Najwa yang sedang menunduk. Hal ini memberikan kesan bahwa Najwa tidak terlalu menyimak 
perkataan Anies. Lalu, saat Basuki sedang memberikan tanggapannya, terdapat angle long shot yang diambil dari sisi Basuki sehingga terlihat eksprsi Anies dari kejauhan, dan kemudian berubah menjadi medium shot yang lebih jelas menangkap ekspresi senyum sinis di wajah Anies.

Di akhir segmen, Najwa
memberikan kesimpulan yang terangkum dalam catatan Najwa, saat Najwa membacakan catatan itu, catatan tersebut juga ikut ditampilkan di layar. Terdapat angle close up wajah Basuki saat Najwa mengatakan ."Perdebatan kini menjadi keniscayaan, sebagai satu tahapan dalam pemilihan. Sebuah langkah penting agar demokrasi tak kembali ke masa-masa genting. Karena sudah terlalu lama mufakat jadi kemutlakan saat menjadi beda dianggap kejahatan" dan tulisan tersebut juga ditampilkan disamping gambar wajah Basuki. Kemudian terdapat angle close up wajah Anies saat Najwa mengatakan "Dari pada diam-diam saling lempar batu”, lalu juga terdapat angle close up wajah Basuki lagi saat Najwa mengatakan "Mendalami masalah rill dengan aksi dipaparkan dengan

cara yang rinci”, hal ini memberikan kesan bahwa kata-kata tersebut merupakan refleksi dari perilaku kedua kandidat selama perjalanan Pilkada DKI ini. Peneliti menganalisa bahwa ada tujuan dan maksud tertentu dari pengambilan angle-angle tersebut. Hal ini juga selaras dengan pemahaman semiotika menurut Roland Barthes, yaitu, dalam sebuah komposisi gambar, penataan elemen-elemen pada gambar tersebut memiliki tanda-tanda yang menimbulkan makna.

Berdasarkan analisa di atas, maka dapat terlihat kemana arah media tersebut berpihak. Seperti yang dikatakan oleh kalangan neo-Marxis, penerus gagasan Karl Marx. Mereka berpendapat bahwa media bukan dipandang sebagai badan yang independen, melainkan sebagai alat ideologis yang dimanfaatkan para pemegang modal untuk mendapatkan keuntungan secara ekonomi dan politik.

\section{STRUKTUR SINTAKSIS Program "Rosi" :}

Dalam episode "Rosi dan Kandidat Pemimpin Jakarta", tidak ada unsur faktual dalam struktur sintaksisnya, karena tidak ada lead dalam episode ini, dan judul dalam episode ini juga cukup obyektif, yaitu "Rosi dan Kandidat Pemimpin Jakarta", namun dalam episode ini peneliti menilai pembingkaian dari struktur sintaksis pada unsur imparsial. Struktur imparsial pada episode "Rosi dan Kandidat Pemimpin Jakarta" ini mengangkat latar informasi tentang pertarungan kedua pasang calon gubernur dan wakil gubernur dengan menampilkan visi misi serta konsep pemikiran antara dua pasang kandidat yaitu Basuki-Djarot dan Anies-Sandi. Dalam debat ini juga dilampirkan kutipan rekaman pembicaraan Djarot dengan tokoh masyarakat kembangan yang berusaha menghadang Djarot. Kemudian sebuah kata kata atau statement dari kedua kandidat yaitu, statment Basuki yang mengatakan "Tiap generasi punya mimpi indah tentang Jakarta. Jangan pernah berhenti bekerjasama dalam mewujudkannya." Kemudian statement dari pendukung Basuki yang suka rela menyumbang untuk dana kampanye serta mengatakan bahwa Basuki adalah gubernur yang paling bagus. Sedangkan statement Anies mengusung para ulama dalam perjuangannya. Hal ini menunjukkan bahwa dalam hal ini Kompas $T V$ yang diwakili oleh program "Rosi" ingin lebih menonjolkan Basuki melalui video yang berisi pencitraan. 
Dari pertanyaan-pertanyaan yang diajukan Rosi terhadap kedua kandidat, ada satu pertanyaan yang menarik perhatian peneliti yaitu, "Singkat saja dari saya, apakah menurut pak Anies dan pak Sandi warga Jakarta tidak bahagia dibawah pemerintahan pak Basuki dan pak Djarot ?", pertanyaan tersebut memberikan kesan bahwa rosi meragukan perkataan Anies yang intinya menganggap warga jakarta tidak bahagia saat dipimpin oleh BasukiDjarot serta terlihat penggalian informasi yang lebih dalam. Dalam acara ini Kompas $T V$ juga berpartisipasi dengan memberikan pertanyaan, yaitu "Untuk pasangan nomor 3, pak Anies dan pak Sandi. Rekam jejak seperti apa yang pernah, yang bisa anda bagi sebagai bagian dari keteladanan kepemimpinan untuk warga Jakarta ?" pertanyaaan tersebut terkesan menyindir kandidat nomor urut 3, mengingat sebelumnya Djarot juga sudah menyinggung soal rekam jejak Anies yang dicukupkan dari jabatannya sebagai mentri pendidikan. Kemudian pertanyaan dari Kompas $T V$ untuk kandidat nomor urut 2 adalah "Untuk pasangan nomor urut 2. Bapak-bapak adalah calon pemimpin ibu kota Jakarta, keteladanan seperti apa yang ingin anda cerminkan?, untuk pak Basuki dan Pak Djarot, anda telah memimpin Jakarta selama ini, keteladanan seperti apa yang TELAH anda cerminkan pada masyarakat Jakarta ?" dalam pertanyaan ini Rosi menekankan kata "Telah" yang dalam detonasi berarti sudah selesai berlangsung. Peneliti menganalisa bahwa melalui pertanyaan itu Rosi ingin menunjukkan bahwa kandidat nomor urut 2 memang telah mencerminkan keteladanan pada masyarakat Jakarta, diperkuat dengan pesan-pesan pencitraan politik pasangan kandidat nomor urut 2 yang memang lebih dulu ditunjukkan dalam acara itu.

Dalam program ini juga menampilkan pertanyaan dari nitizen. Dari ribuan pertanyaan yang masuk, pihak "Rosi" memilih 2 pertanyaan yaitu, "Menurut masing-masing pasangan cagub, seperti apakah contoh praktik money politics yang harus dihindari saat kampanye ?" yang ditunjukkan untuk pasangan Anies-Sandi, dalam hal ini cukup jelas terlihat bagaimana Kompas $T V$ melakukan penggiringan opini. Pertanyaan tersebut bukan dipilih tanpa alasan. Jika kita telaah lebih jauh pertanyaan tersebut sangat menyinggung kandidat nomor 3 mengingat kasus dana kampanye sumbangan Sandiaga Uno yang mendominasi pendanaan kampanye kandidat nomor urut 3 yang menjadi viral di berbagai media. Sedangkan pertanyaan dari nitizen untuk pasangan Basuki-Djarot adalah "Gimana ya caranya merelokasi tanpa menggusur ?" sekilas pertanyaan ini memang terlihat tepat ditujukan pada Basuki, tetapi jika kita telaah lebih jauh, tim Rosi memilihkan pertanyaan tersebut untuk Basuki bukan karena memang untuk Basuki, namun untuk menyindir kandidat nomor 3, karena di setiap kampanye yang dilakukan, kandidat nomor urut 3 selalu mengatakan untuk tidak menggusur karena sebenarnya bisa dilakukan relokasi tanpa menggusur tetapi menata. Dan tidak hanya itu, pertanyaan ini juga membuka kesempatan bagi pasangan BasukiDjarot untuk menyerang Anies. Berdasarkan analisa di atas, maka selaras dengan apa yang dikatakan Van Zoest (1991:70), bahwa sebuah teks tak terlepas dari ideologi dan memiliki kemampuan untuk memanipulasi pembaca atau pemirsa ke arah suatu ideologi. 
STUKTUR SKRIP Program "Rosi"

Unsur imparsial dari konsep obyektivitas menurut peneliti adalah pemilihan narasumber. Dalam porsi pemilihan narasumber sudah cukup proporsional, yakni Basuki Tjahya Purnama dan Djarot Saiful Hidayat di sebelah kiri Rosi, namun Rosi terkesan lebih dekat dan akrab pada pasangan Basuki-Djarot dan dapat dilihat dari cara Rosi bercanda dengan pasangan tersebut dan lebih intim mengomentari perubahan sikap Basuki yang menjadi lebih santun. Sedangkan pasangan Anies Rasyid Baswedan dan Sandiaga Uno ditempatkan di sebelah kanan Rosi. Berdasarkan penempatan duduk ini, peneliti menganalisa bahwa tim Rosi sudah memiliki arah pemikiran tertentu, membela suatu pihak yang terbilang berada di ideologi politik yang sama dengan Kompas $T V$.

\section{STRUKTUR TEMATIS Program "Rosi"}

Secara faktual, Saat Basuki selesai menyampaikan visi misinya dalam Pilkada, rosi langsung mengeluarkan sebuah pernyataan yang mengindikasikan kedekatan Rosi dengan pasangan Basuki-Djarot . "pak Djarot senyum lega, ada yang berubah dari pak Ahok, lebih lembut kayaknya pak Djarot”. Kalimat tersebut memberikan kesan bahwa Rosi begitu memperhatikan Basuki sehingga bisa sampai mengetahui perubahan sikap yang terjadi pada Basuki. Cara Rosi berbicara pun terkesan dekat dan tidak ada jarak antara moderator dan pasangan kandidat tersebut. Pernyataan tersebut juga sekaligus membuka celah bagi Djarot untuk melakukan pencitraan tentang Basuki. dengan kata lain, program "Rosi" melakukan penggiringan opini yang mengkonstruksi pesan pencitraan politik dari kubu Basuki-Djarot. Hal ini selaras dengan paradigma konstruksionis menurut pemahaman Eriyanto.

Penarikan kesimpulan pada episode ini adalah ucapan terimakasih dari Rosi kepada para kandidat yang telah berani berada dalam satu panggung untuk beradu visi misi. Rosi mengucapkan beberapa kali rasa terimakasih itu. Dari cara Rosi tersebut peneliti menganalisa bahwa Rosi agak sedikit menyindir pasangan kandidat nomor 3 yang kerap tidak hadir memenuhi undangan Rosi di acaraacara sebelumnya. Secara imparsial, porsi yang diberikan untuk kedua kandidat berbeda tipis. Peneliti mencoba menghitung durasi berbicara yang di berikan pada Basuki dan yang diberikan pada Anies. Waktu dihitung sejak kandidat mulai mengeluarkan suara hingga berhenti berbicara. Waktu yang digunakan pasangan BasukiDjarot untuk berbicara dalam debat tersebut baik dalam menjawab pertanyaan maupun menanggapi jawaban kandidat lainnya adalah 33,9 menit. Sedangkan Anies 34,5 menit. Dengan kata lain, Anies memiliki waktu yang lebih panjang 56 detik. Meskipun begitu, peneliti masih menganggap ini suatu hal yang wajar mengingat durasi keseluruhan yang cukup panjang serta memang Anies sering melewati batas durasi saat berbicara.

\section{STRUKTUR RETORIK Program "Rosi"}

Secara faktual, terdengar suara tawa Rosi yang begitu menikmati hiburan stand up comedi yang ditampilkan oleh pasangan BasukiDjarot, selain itu, di awal sebelum pasangan Basuki-Djarot menampilkan hiburan tersebut, terdengar suara Rosi dengan nada yang sangat antusias ingin melihat hiburan yang ditampilkan oleh Basuki-Djarot, Kemudian diiringi sebuah candaan yang begitu akrab 
antara Rosi dan Basuki serta ucapan terimakasih banyak atas penampilan hiburan. Sedangkan saat pasangan Anies-Sandi menampilkan hiburan dengan nyanyian "Rindu Rasul" Rosi tampak biasa saja dan hanya sedikit menanggapi setelahnya.

Secara imparsial, terdapat beberapa angle gambar yang dianggap memberikan penggiringan opini menurut peneliti, yaitu angle long shot saat Rosi duduk di podium sempat menampilkan gambar pasangan BasukiDjarot di meja Rosi tersebut. Sekilas memang terkesan biasa karena acara tersebut adalah acara debat sehingga wajar ada gambar kandidat, namun gambar yang ada di meja tersebut hanyalah gambar kandidat nomor 2 sedangkan kandidat yang lain tidak ada. Kemudian terdapat angle long shot yang menangkap gambar Basuki-Djarot yang sedang asyik mengobrol saat Anies sedang berbicara. Gambar ini menandakan bahwa tim Rosi ingin menunjukkan bahwa Anies bukanlah lawan yang berat bagi Basuki karena Basuki terlihat santai menghadapi Anies. Lalu ada angle medium close up yang mengambil ekspresi Anies yang cemberut saat Basuki sedang berbicara. Kemudian peneliti juga menemukan ada angle close up yang menangkap ekspresi pendukung Basuki yang tertawa sambil menunjuk saat Anies tidak bisa mengikuti nyanyian yang dicontohkan Tompi. Dari hal tersebut peneliti menemukan adanya penggiringan opini dan maksud tertentu yang dibentuk oleh Kompas $T V$ melalui program "Rosi", selaras dengan pemahaman semiotika menurut Roland Barthes, yaitu, dalam sebuah komposisi gambar, penataan elemen-elemen pada gambar tersebut memiliki tanda-tanda yang menimbulkan makna. Selain itu, durasi penampilan hiburan dari simpatisan Basuki-Djarot lebih lama, yaitu 5 menit 24 detik, sedangkan penampilan hiburan dari simpatisan Anies-Sandi hanya 2 menit 45 detik. Berdasarkan analisa tersebut dapat terlihat kemana arah penggiringan opini yang ingin dibentuk Kompas TV melalui Program Rosi. Dengan demikian, fakta yang disajikan dalam program tersebut telah terarah dan terbentuk berdasarkan suatu ideologi. Hal ini selaras dengan teori konstruksi realitas sosial yang dicetuskan oleh Berger dan Luckman

\section{Kesimpulan dan Saran}

Terdapat pengaruh kepentingan bisnis di balik pemilik televisi. Meski porsinya berbeda antara kedua talkshow, namun tetap terlihat di presentasi progam secara keseluruhan. Terlihat sekali dalam kemasan program "Mata Najwa" sangat menyudutkan kandidat nomor urut 3 yaitu Anies Baswedan yang sifatnya oposisi karena Anies menentang proyek reklamasi yang merupakan investasi dari pemilik Metro TV. Sementara "Rosi" terlihat lebih akrab dan dekat dengan pasangan kandidat nomor urut 2 yaitu Basuki Tjahya Purnama dan Djarot Saiful Hidayat yang mengindikasikan ada kepentingan bisnis pemilik media dengan kandidat tersebut.

Pembawa acara memegang kendali yang besar dalam membingkai isu. Rosiana Silalahi sebagai Pemimpin Redaksi Kompas TV memiliki kendali yang kuat akan pembingkaian berita, khususnya di "Rosi". Rosi terlihat lebih dekat dengan Basuki ketimbang Anies, bahkan Rosi sering berbasa-basi serta melakukan candaan dengan pasangan kandidat nomor urut 2 tersebut. Hal tersebut tersirat dari bingkai yang digunakan; yaitu "berkomentar tentang sikap Basuki yang lebih lembut", Begitupun dengan Najwa Shihab selaku Wakil Pemimpin Redaksi Metro TV 
leluasa membingkai berita, terlebih pada program yang dipandunya; "Mata Najwa". Najwa sangat terlihat memiliki tendensi untuk melakukan pembingkaian dan cenderung bersikap tegas pada Anies ketimbang pada Basuki, terutama soal durasi. Penggalian informasi juga lebih dalam menyoroti Anies.

Ada media yang mengabaikan obyektivitas dan mengedepankan isuisu yang hanya dianggapnya penting. Terlihat pada program "Mata Najwa" dari segi pemilihan narasumber, penayangan eksklusif wawancara, serta tidak memisahkan opini dan fakta. Ada juga media yang menerapkan obyektvitas di atas kepentingan lain yang dimiliki perusahaan. Hal ini terlihat pada Kompas $T V$, meskipun memilih untuk mengesampingkan unsur politik guna terlihat obyektif, namun perlakuan yang diberikan Rosi terhadap kedua kandidat begitu berbeda dan sangat terasa ada unsur keberpihakan yang melekat pada Rosi.

\section{Saran}

1. Agar insan komunikasi lebih kritis dan skeptis dalam memahami pesan suatu berita. Masyarakat perlu diedukasi dengan pemahaman yang netral akan sebuah peristiwa agar memiliki wawasan yang luas dan tidak terburu-buru melakukan judgement negatif atas suatu peristiwa.Masyarakat juga harus bisa menelaah lebih lanjut atas sebuah informasi dan tidak menelan bulat-bulat informasi yang mereka dapat melalui media. Media seringkali tidak tepat dalam memaknai sebuah peristwa, juga tidak jarang ada kepentingan lain yang menyebabkan terjadi bias makna dalam suatu pesan berita.
2. Agar penelitian selanjutnya bisa lebih kritis dan mendalam, serta mengembangkan metode analisis framing sehingga hasil penelitian bisa lebih beragam dan menambah referensi bagi penelitian selanjutnya.

3. Untuk penelitian selanjutnya diharapkan bisa lebih berani dalam mengambil anglesehingga sudut pandang penelitian tidak monoton dan melulu menggunakan teori yang itu-itu saja.

4. Untuk penelitian selanjutnya disarankan untuk lebih detail lagi dalam melihat pembingkaianatas suatu peristiwa yang dibentuk media, sehingga hasil penelitian bisa lebih valid dan memiliki argumen yang kuat.

5. Untuk penelitian selanjutnya diharapkan bisa menggunakan jenis framing yang lain agar penelitian sejenis bisa terus berkembang.

\section{Daftar Pustaka}

Armando, A. (2016). Televisi Indonesia Di Bawah Kapitalisme Global. Jakarta: PT. Media Kompas Nusantara.

Cevilia, C. G. (1993). Pengantar Metode Penelitian. Jakarta: Universitas Indonesia.

Eriyanto. (2002). Analisis Framing: Konstruksi, Ideologi dan Politik Media. Yogyakarta: LkiS.

Kovach, B. (2001). The Elements of journalism: What Newspeople and The Public Hould Expect. New York: Crown.

Ks, U. (2009). Ekonomi Media: Pengantar Konsep dan Aplikasi. Bogor: Ghalia Indonesia. 
100 | Indrabayu Muhammad, et al.

Luckmann, P. L. (1962). The Social Constuction Of Reality.

Moleong, L. J. (1993). Metodologi Penelitian Kualitatif. Bandung: Remaja Rosdakarya.

Morissan. (2008). Manajemen Media Penyiaran: Strategi Mengelola Radio \&. Jakarta: Kencana prenada Media Grup.

Rakhmat. (1994). Psikologi Komunikasi. Bandung: Remaja Rosdakarya offset.

Reese, P. J. (1996). Mediating The Message Second Edition. New York: Longman.

Sobur, A. (2016). Semiotika Komunikasi. Bandung: PT. Remaja Rosdakarya.

Tuchman, G. (1978). Making News: A Study in The Construction of Reality. New York: Free Press.

W, D. M. (1993). Communication Model For The Study of Mass Communication. London: Longman.

Zettl, H. (2012). Television Production Handbook. Boston: wadsworth. 